木質系・草本系バイオマスによる半炭化燃料の熱分解モデルに基づく発熱量推定

\title{
Estimation of $H H V$ based on pyrolysis model of Torrefied fuel using woody and herbaceous biomass
}

学 ○森山 史哉 （近大大学院）正 澤井 徹 （近大）

Fumiya Moriyama, Graduate school of Kindai University, 3-4-1, kowakae, higashi-osakashi, Osaka Toru Sawai, Kindai University

\section{1 緒 言}

化石資源由来の $\mathrm{CO}_{2}$ を効果的に削減する方法として, 既存 の石炭火力発電設備を利用したバイオマスと石炭の混焼発 電が注目されている。

バイオマスの混焼割合を向上させるためには, 発熱量の改 質に加えて良好な微粉砕特性を有する半炭化バイオ固体然 料の導入が有効である.ところが，半炭化バイオ固体燃料の 発熱量は, これまで樹種ごとに実験的に求められてきている。 本研究では, 半炭化バイオマスの熱分解特性を Two-step 反 応モデルを用いて表すことができると仮定して，半炭化燃料 の組成を考慮した発熱量推定モデルの構築を検討した. 著者 らの先行研究 1)では灰分率が $1 \%$ 未満のスギを対象に上記検 討を行ってきたが，ここでは灰分を多く含む草本系バイオマ スへ適用するため, 灰分を考慮した熱分解モデルによる発熱 量推定モデルの提案を行う.

\section{$2 \cdot 1$ 実験試料・方法}

\section{2 実験・解析方法}

半炭化熱分解実験で使用した試料は稲わらである. 洗浄, 乾燥, 粉砕後, 分級した粒径 53-150 $\mu \mathrm{m}$ の試料を $30 \mathrm{mg}$ 準備 乙, 熱天科を用いて等温熱分解実験（熱分解温度 $\mathrm{T}_{\mathrm{p}}$ は 230 , $250,270,290,310^{\circ} \mathrm{C} の 5$ 通り, 熱分解時間 $\mathrm{t}_{\mathrm{p}}$ は $0.5,1,2$, 4h の 4 通り）を行った。 なお，スギと稲わらのISO による工 業分析結果は以下のとおりである.

稲わら：揮発分 $77.3 \%$, 固定炭素 $13.9 \%$, 灰分 $8.8 \%$ スギ : 揮発分 $82.2 \%$ ，固定炭素 $17.1 \%$ ，灰分 $0.69 \%$

\subsection{Two-step 反応速度モデル}

Two-step 反応速度モデルでは, 第一反応で生バイオマス (RB) から揮発成分 1（V1）と反応中間体 (IM) が生成され, 続いて第二反応で IM から揮発成分 2（V2） と炭化成分（C) が生成される.ここで全ての反応は 1 次反応を仮定し, V1, $\mathrm{IM}, \mathrm{V} 2 ， \mathrm{C}$ 生成の反応速度定数を $k_{\mathrm{v} 1}, k_{\mathrm{I}}, k_{\mathrm{v} 2}, k_{\mathrm{C}}$ と寸 る. RB，V1，IM，V2，C の時刻 $\mathrm{t}$ における質量 $[\mathrm{kg}]$ を $M_{\mathrm{R}}(\mathrm{t})$, $M_{\mathrm{v} 1}(\mathrm{t}), M_{\mathrm{I}}(\mathrm{t}) ， M_{\mathrm{v} 2}(\mathrm{t}) ， M \mathrm{c}(\mathrm{t})$ とするとそれぞれの質量収率は反 応速度モデルから式(1)〜(5)で与えられる.ただし， $K_{1}=k_{\mathrm{v} 1}$ $+k 1, K_{2}=k v_{2}+k \mathrm{c}$ であり, $M \mathrm{o}[\mathrm{kg}]$ は熱分解前の全乾試料の質 量, $\mathrm{A}[\%]$ は灰分の初期質量分率である.

$$
\begin{aligned}
& \frac{M_{\mathrm{R}}(t)}{M_{\mathrm{o}}}=\left(1-\frac{A}{100}\right) e^{-K_{1} t} \\
& \frac{M_{\mathrm{v}}(t)}{M_{\mathrm{o}}}=\left(1-\frac{A}{100}\right) \frac{k_{\mathrm{v} 1}}{K_{1}}\left(1-e^{-K_{1} t}\right) \\
& \frac{M_{1}(t)}{M_{\mathrm{o}}}=\left(1-\frac{A}{100}\right) e^{-K_{2} t} \times\left(\frac{K_{\mathrm{V}}}{K_{1}}\left(e^{-\left(K_{2}-K_{1}\right) t}-1\right)\right) \\
& \frac{M_{\mathrm{V} 2}(t)}{M_{\mathrm{o}}}=\left(1-\frac{A}{100}\right) k_{1} k_{\mathrm{V} 2} \times \frac{1}{K_{2}-K_{1}}\left(\frac{1}{K_{1}}\left(1-e^{-K_{1} t}\right)-\frac{1}{K_{2}}\left(1-e^{-K_{2} t}\right)\right) \\
& \frac{M_{C}(t)}{M_{\mathrm{o}}}=\left(1-\frac{A}{100}\right) k_{1} k_{\mathrm{C}} \times \frac{1}{K_{2}-K_{1}}\left(\frac{1}{K_{1}}\left(1-e^{-K_{1} t}\right)-\frac{1}{K_{2}}\left(1-e^{-K_{2} t}\right)\right)
\end{aligned}
$$

ここで半炭化バイオ固体燃料は生バイオマス, 反応中間体, 炭化成分, 灰分で構成されており, 灰分は反応が進んでも質 量に変化がないものとして解析を行った. 上記反応速度モデ ルで得られる半炭化燃料の質量収率 $\left(M_{\mathrm{R}}(t)+M_{\mathrm{I}}(t)+\right.$ $\left.M_{\mathrm{C}}(t)+A\right) / M_{0}$ を実験データと非線形最小 2 乗フィッティン グを行い, 各反応速度定数を決定する. 得られた反応速度定 数は温度依存性を示すアレニウス則に従うものとする. $\mathrm{t}_{\mathrm{p}}=4 \mathrm{~h}$ の各熱分解温度に対してアレニウスプロットを行い, 頻度因 子 $\mathrm{A}_{\mathrm{i}}$ ，活性化エネルギー $\mathrm{E}_{\mathrm{i}}$ を決定した。

\section{3 発熱量 $H H V$ の推定モデル}

与えられた熱分解温度, 熱分解時刻で製造された半炭化燃 料は, RB，IM，C，Aの 4 つの固体成分で構成されている. 半炭化燃料の高位発熱量 $H H V_{\mathrm{T}}[\mathrm{MJ} / \mathrm{kg}]$ は各成分の高位発熱 量 $H H V_{\mathrm{R}}[\mathrm{MJ} / \mathrm{kg}], H H V_{\mathrm{I}}[\mathrm{MJ} / \mathrm{kg}], H H V_{\mathrm{C}}[\mathrm{MJ} / \mathrm{kg}], H H V_{\mathrm{A}}[\mathrm{MJ} / \mathrm{kg}]$ および半炭化燃料中の $\mathrm{RB}, \mathrm{IM}, \mathrm{C}, \mathrm{A}$ の質量分率 $x_{\mathrm{R}}, x_{1}, x_{\mathrm{C}}$, $x_{\mathrm{A}}$ を用いて式（6）で表されるものとする.

$$
H H V_{\mathrm{T}}=x_{\mathrm{R}} \times H H V_{\mathrm{R}}+x_{\mathrm{I}} \times H H V_{\mathrm{I}}+x_{\mathrm{C}} \times H H V_{\mathrm{C}}+x_{\mathrm{A}} \times H H V_{\mathrm{A}}
$$

式中の $x_{\mathrm{R}}, x_{\mathrm{I}}, x_{\mathrm{C}}$ は式(1), (3), (5)から推定可能であり, $H H V_{\mathrm{R}}$ は RB の発熱量で与えれ, 灰分の発熱量はゼロである. しかし $H H V_{\mathrm{T}}$ の推定のためには, $H H V_{\mathrm{I}}$ と $H H V_{\mathrm{C}}$ の見積もりが 必要となる. 先行研究により, $H H V_{\mathrm{C}}$ と $H H V_{\mathrm{I}}$ は熱分解時間の 変化に依らず熱分解温度にのみ依存することが分かってい る ${ }^{2)}$. そこで本研究では, 所定の熱分解温度で熱分解時間を 変えた実験結果から 2 つの未知数 $H H V_{\mathrm{C}}$ と $H H V_{\mathrm{I}}$ を求め, $H H V_{\mathrm{T}}$ を推定した.

\section{4 結 果}

本研究で提案した灰分を考慮した Two-step 反応速度モデ ルに基づく発熱量推定モデルの予測值の正確度を評価する ため, 実験データとの比較を行った。この結果，スギ，稲 わらの場合, 予測値と実験結果を比較したグラフから得ら れる決定係数 $\mathrm{R}^{2}$ はそれぞれ $0.971 ， 0.944$ となり，高い精度 で予測しうることが明らかとなった。

\section{参考文献}

1) 森山 史哉, 澤井 徹, ”半炭化スギ木粉 Two-step 熱分解モデ ルで生成される固体物質の発熱量” 日本実験力学会 2019 年度 年次講演会 (二○一九・九 $)$

2) 森山 史哉, 澤井 徹, ” 半炭化スギ木粉 Two-step 熱分解モデ ルで生成される反応中間体の発熱量推定” 日本機械学会 第 二九回環境工学総合シンポジウム二○一九講演論文集（二○ 一九・六） No.19-4, pp.160-163 